DOI: $10.21802 / \operatorname{artm} .2019 .4 .12 .80$.

УДК 577.122.385+616-085+612.176+616.126+615.03

\title{
ВПЛИВ L-АРГІНІНУ ТА ОСОБЛИВОСТІ ФАРМАКОКОРЕКЦІЇ СТАНУ ЕНДОТЕЛІЮ СЕРЦЯ ЩУРІВ В УМОВАХ ДІЇ ЕМОЦІЙНО-БОЛЬОВОГО СТРЕСУ, УСКЛАДНЕНОГО ГІПЕРХОЛЕСТЕРИНЕМІЕЮ
}

\author{
I.M. Лучко, Т.В. Гуранич, O.I. Тучак, С.О. Петруняк, I.O. Назарук \\ Івано-Франківський національний медичний університет, кафедра фізіології, \\ м. Івано-Франківськ, Украӥна, \\ ORCID ID: 0000-0003-3282-0890, \\ e-mail: fisiology@ifnmu.edu.ua
}

Резюме. Метою роботи було вивчення стану ендотелію ендокарду щурів (за кількістю злущених клітин) при емоційно-больовому стресі, ускладненому гіперхолестеринемією та за умов корекції фармакологічними препаратами. Для відтворення стресу використовували електро-імпульсну модель. Аліментарну гіперхолестеринемію моделювали, утримуючи тварин на атерогенній дієті. Окрім L-apгініну, застосовували такі фармакологічні препарати: $\beta$-адреноблокатор (пропранолол), блокатори Са ${ }^{2+}$-каналів (фіноптин) і циклооксигеназ (індометацин). Стан ендотелію ендокарду вивчали за допомогою світлооптичної мікроскопії, аналізуючи мазки-відбитки 3 макропрепаратів шлуночків. Установлено, що пероральне використання L-аргініну суттєво попереджує пошкодження ендотеліоцитів ендокарду при емоційно-больовому стресі і $\epsilon$ неефективним при стресі, ускладненому гіперхолестеринемію. Серед інших фармакологічних середників вираженою цитопротекторною дією при стресі володіють $\beta$-адреноблокатори та блокатори кальцієвих каналів. В умовах стресорного впливу гіперхолестеринемія суттєво обмежує захисну дію згаданих препаратів. Отримані результати та їх аналіз дозволяють припустити, що в патогенезі структурнофункціональних змін ендотеліоцитів ендокарду та розвитку ендотеліальної дисфункції в умовах емоційнобольового стресу, а також при його поєднанні з гіперхолестеринемією, важливою ланкою є токсична дія катехоламінів, які впливають на функціональні системи організму переважно через $\beta$-адренорецептори (за участю іонів $\mathrm{Ca}^{2+}$ ). Певну захисну роль відіграють, очевидно, простагландини, оскільки блокада їх синтезу індометацином поглиблює ураження ендотеліоцитів.

Ключові слова: аргінін, фармакологічні середники, ендотелій, стрес, гіперхолестеринемія.

Вступ. Обгрунтування дослідження. Важливе значення у регуляції судинного тонусу та підтриманні агрегатного стану крові має оксид азоту (NO), який синтезується в ендотелії судин, у тому числі і коронарних, із амінокислоти L-аргініну [3, 4, 7]. На даний час $\epsilon$ дані експериментальних та клінічних досліджень, які, з одного боку, вказують на порушення функції ендотелію судин і синтезу ним NO при дії таких факторів як стрес та гіперхолестеринемія (ГХЕ) [2, 8, 9], 3 іншого - на можливу цитопротективну дію у відношенні до ендотеліоцитів субстрату для синтезу NO L-аргініну $[4,5]$. Зокрема, встановлено, що введення L-аргініну зменшує зону некрозу при експериментальній ішеміï/реперфузії, попереджує зрушення показників прооксидантно-антиоксидантного гомеостазу та функціонування мітохондрій при циркуляторногемічній гіпоксії $[5,10]$. На даний час маловивченим залишається поєднаний вплив основних патоендотеліотропних факторів: стресу та підвищення в крові рівня вільного холестерину (ХC), а також можливість застосування 3 протекторною метою L-аргініну.

Результати багатьох досліджень, які стосуються дії згаданих чинників на структурні компоненти серця і судин, показують, що в реалізації стресових пошкоджень беруть участь ряд механізмів, ключовими 3 яких $є$ кальцієві, токсичний вплив підвищеного рівня в крові катехоламінів, активація процесів перекисного окислення ліпідів, дисбаланс у синтезі простагландинів $[1,5]$.

Мета дослідження. Вивчити вплив екзогенного L-аргініну, блокаторів $\mathrm{Ca}^{2+}$-каналів, $\beta$ адренорецепторів і циклооксигеназ на стан ендотелію ендокарда лівого шлуночка в умовах дії емоційнобольового стресу (ЕБС) та при його поєднанні з ГХЕ.

Матеріали i методи. Дослідження проводилися на 66 безпородних білих щурах-самцях масою 180-240 г, які перебували в звичайних умовах віварію. Утримання тварин та експерименти на них проводилися згідно з Положенням «Європейської конвенції про захист хребетних тварин, що використовуються для дослідних та наукових цілей» (Страсбург, 1986) та «Загальних етичних принципів експериментів на тваринах», ухвалених Першим Національним конгресом 3 біоетики (Київ, 2001). Тварини були розподілені на три групи: 1-ша контрольна група, 2-га - тварини, які піддавалися трьохгодинній дії стресора, 3-тя - тварини, що зазнавали стресового впливу на тлі ГХЕ. У 2-ій та 3ій групах виділялися підгрупи тварин, яким перед впливом стресора вводили препарати: L-аргінін (100 мг/кг, LAPHAL", Франція, перорально за допомогою зонду за 1 год до дії стресора); пропранолол, як $\beta$ - 
адреноблокатор (0,5 мг/кг, „Здоров'я”, Україна, одноразово внутрішньовенно безпосередньо перед початком стресового впливу); індометацин блокатор циклооксигеназ (10 мг/кг, „Здоров'я”, Україна, перорально за допомогою зонду за 90 хв до початку дії ЕБС); фіноптин - блокатор $\mathrm{Ca}^{2+}$-каналів (2,5 мг/кг, „Orion”, США, внутрішньом'язово за 30 хв до стрес-реакції).

Для відтворення ЕБС використовувалася електро-імпульсна модель [6]. Аліментарну ГХЕ моделювали шляхом щоденного введення через зонд в ротову порожнину 250 мг холестерину в 1 мл свинячого сала із обов'язковим додаванням жовчних кислот. Щури знаходилися на атерогенній дієті протягом 60 діб. Контроль рівня загального ХС у сироватці крові проводили фотометричним методом. Евтаназію тварин здійснювали під кетаміновим наркозом («Фармак», Україна) 3 розрахунку 100 мг/кг маси тіла. Забір матеріалу проводили через 24 год після трьохгодинного стресового впливу.

Для дослідження стану ендотелію ендокарду готували мазки-відбитки 3 макропрепаратів лівого шлуночка щурів, прикладаючи їх до предметних скелець, які фарбували за методом Романовського. Ступінь пошкодження ендотелію ендокарду визначали за кількістю злущених клітин на 1 мм $^{2}$ площі відбитку, що відповідає 40 полям зору (ок. $\times 7$; об. ×90). Одержані дані оброблені статистично за допомогою комп'ютерних програм Microsoft Excel та Statistica 7.0.

Результати дослідження та їх обговорення. У результаті проведених досліджень установлено, що через 24 год після трьохгодинної стрес-реакції кількість злущених ендотеліоцитів у мазкахвідбитках збільшується у 4,5 рази порівняно 3 контролем $(\mathrm{p}<0,001)$ (див. табл. 1). У тварин, що перебували на атерогенній дієті, концентрація загального холестерину у сироватці крові підвищується на $45,3 \%$. Такий рівень ГХЕ супроводжується вираженим пошкодженням ендотеліоцитів ендокарда при дії ЕБС (зростання у $6,5$ разів, $\mathrm{p}<0,001)$.

Таблиця 1

Кількість злущених ендотеліоцитів (кл/мм²) у мазках-відбитках $з$ ендокарду лівого шлуночка тварин при ЕБС, ЕБС, ускладненому ГХЕ, та за умов фармакологічної корекції $(\mathrm{M} \pm \mathbf{m}, \mathbf{n}=6)$

\begin{tabular}{|l|c|c|c|}
\hline \multirow{2}{*}{$\begin{array}{c}\text { Групи тварин та } \\
\text { фармакологічні препарати }\end{array}$} & \multicolumn{3}{|c|}{ Умови експерименту } \\
\cline { 2 - 4 } 1-ша - контрольна & інтактні тварини & ЕБС, 3 год & ЕБС (3 год) + ГХЕ \\
\hline Корекція: & $24,3 \pm 1,7$ & $107,9 \pm 4,9^{*}$ & $156,1 \pm 8,2^{*}$ \\
2-га - L-аргініном & - & $84,2 \pm 3,4^{*}$ & $151 \pm 3,6^{*}$ \\
& - & $\mathrm{p}_{1-2}<0,005$ & $114,3 \pm 6,7^{*}$ \\
\multirow{3}{*}{ 3-тя - фіноптином } & - & $55 \pm 3,2^{*}$ & $\mathrm{p}_{1-3}<0,001$ \\
\cline { 2 - 4 } & - & $39,0 \pm 3,5^{*}$ & $74,9 \pm 5,1^{*}$ \\
4-та - пропранололом & - & $\mathrm{p}_{1-3}<0,001$ & $\mathrm{p}_{1-4}<0,001$ \\
\cline { 2 - 4 } 5-та - індометацином & - & $143,8 \pm 6,3^{*}$ & $233,7 \pm 6,5^{*}$ \\
& - & $\mathrm{p}_{1-5}<0,001$ & $\mathrm{p}_{1-5}<0,001$ \\
\hline
\end{tabular}

Примітка. * - достовірно у порівнянні з інтактними тваринами

Отримані результати свідчать, що використання екзогенного L-аргініну перед стресорним впливом у тварин, які отримували звичайну їжу, обмежує пошкодження ендотеліальної вистилки на $22,2 \% \quad(\mathrm{p}<0,001)$. У той же час, статистично достовірної різниці між групами «ЕБС + ГЕЕ та «ЕБС + ХХЕ $+\mathrm{L}-$-аргінін» по цьому показнику не спостерігається.

Серед досліджуваних нами фармакологічних середників виражену цитопротекторну дію у відношенні до ендотелію ендокарду лівого шлуночка щурів проявляють $\beta$-адреноблокатор пропранолол та блокатор $\mathrm{Ca}^{2+}$-каналів фіноптин, які при ЕБС зменшують десквамацію ендотеліоцитів відповідно на $63,9 \%$ i $40,1 \% \quad(p<0,001)$. Введення перед початком дії стресора індометацину, навпаки, супроводжується підсиленням (на $33,3 \%$, (p <0,001) злущення ендотеліальних клітин.

Також установлено, що при стресі, ускладненому ГХЕ, у дії застосованих препаратів зберігається така ж тенденція, але їх фармакологічний ефект є менше вираженим. Зокрема, є слабкішою цитопротекторна дія пропранололу i фіноптину. Під їх впливом ступінь пошкодження ендотелію ендокарду знижується (відповідно на $51,9 \%$ і 26,9\%, (p <0,001) але у меншій мірі, ніж у попередньому випадку. Використання індометацину призводить до підсилення десквамації ендотеліоцитів на $50,0 \%(\mathrm{p}<0,001)$.

Отже, ГХЕ при ЕБС у значній мірі обмежує захисну дію пропранололу і фіноптину та практично нівелює вплив L-аргініну. При використанні індометацину в умовах стресу, ускладненого ГХЕ, ще більше підсилюється десквамація ендотеліоцитів ендокарду.

Таким чином, отримані результати, їх аналіз та співставлення із даними літературних джерел дозволяють зробити висновок, що при дії ЕБС та ЕБС, поєднаного з ГХЕ, ураження ендотеліоцитів ендокарда залежить від впливу ендогенних чинників, зокрема: активації адренорецепторів, посилення процесів перекисного окислення ліпідів та стимуляції агрегації тромбоцитів $[1,3,5]$. При ГХЕ відбувається зміна властивостей клітинних мембран у зв'язку 3 
накопиченням у них холестерину [1, 5], що супроводжується зміною форми окремих ендотеліоцитів і розкриттям міжклітинних контактів, а також зникненням глікокаліксу.

Пероральне застосування L-аргініну як основного субстрату для синтезу NO проявляється суттєвим покращенням структурно-функціонального стану ендотеліоцитів ендокарда при дії ЕБС. Захисний ефект NO по відношенню до ендотелію пов'язаний, очевидно, 3 двома механізмами. Поперше, NO має здатність активувати в ендотеліоцитах цитоплазматичну гуанілатциклазу, що призводить до збільшення концентрації цГМФ і, відповідно, до зменшення внутрішньоклітинної концентрації $\mathrm{Ca}^{2+}$. По-друге, NO пригнічує агрегацію тромбоцитів до поверхні цих клітин, чим попереджує пошкодження ендотеліальної висилки [7, 10]. При поєднаній дії ЕБС та ГХЕ вказані ефекти, ймовірно, є недостатніми для попередження пошкодження ендотеліоцитів.

Результати застосування $\beta$-адренорецепторів та блокаторів кальцієвих каналів підтверджують той факт, що ураження ендотеліоцитів ендокарда при емоційному стресі реалізується, у першу чергу, через вплив катехоламінів на $\beta$-адренорецептори за участю іонів $\mathrm{Ca}^{2+}$, що $\epsilon$ співзвучним із даними інших літературних джерел $[1,5,6]$. Збільшення синтезу простагландинів при ЕБС (зокрема простацикліну) [3, 5] носить, очевидно, компенсаторний характер i обмежує пошкоджуючий вплив стресора на ендотелій. Цей факт підтверджується негативним результатом використання нами при ЕБС блокатора циклооксигеназ індометацину.

\section{Висновки:}

1. Пероральне використання L-аргініну суттєво попереджує пошкодження ендотеліоцитів при ЕБС і $є$ неефективним при стресі, ускладненому ГХЕ.

2. У патогенезі структурно-функціональних змін ендотеліоцитів ендокарду та розвитку ендотеліальної дисфункції в умовах ЕБС та його поєднання з ГХЕ важливою ланкою є токсична дія катехоламінів, які впливають на функціональні системи організму переважно через $\beta$-адренорецептори та за участю іонів $\mathrm{Ca}^{2+}$. Простагландини, очевидно, відіграють захисну роль, оскільки блокада їх синтезу індометацином поглиблює ураження ендотеліоцитів.

3. ГХЕ аліментарного походження потенціює пошкоджуючу дію стресу на ендотелій ендокарду, що супроводжується різким збільшенням кількості злущених клітин, а також, з іншого боку, обмежує протекторний вплив деяких фармакологічних препаратів.

\section{References:}

1. Baraboy VA, Reznikov OG. Fiziologiia, biokhimiia $i$ psykhologiia stresu: monografiia. K: Interservis; 2013. P.313.

2. Vatseba MO. Kliniko-diagnostychne znachennia endoteliynoi dysfunktsiyi ta arteriynoyi zhorstkosti $u$ khvorykh na arteriynu gipertensiyu $u$ poyednanni iz ozhyrinnyam ta podagroyu. Lviv. med. chasopys. 2014; 20(1):48-52.
3. Vozna KhI, Moskaliuk VD. Endoteliy: funktsionalni vlastyvosti ta yogo dysfunktsiya. Inf. Khvoroby. 2015; 1:66-71.

4. Zhdan VM, Katerenchuk IP. Kardio- ta endoteliyprotektorni vlastyvosti kardioargininu pry komorbidniy patologiyi u praktytsi simeynogo likarya. Ukrayina. Zdorovia natsiyi. 2016; 1/2:237.

5. Igrunova KM. Mekhanizmy rozvytku poshkodzhen sertsya ta yikh korektsiya. Vinnytsya: Merkyuri-Podillya; 2014. P.239.

6. Luchko IM, Guranych TV, Popadynets OG, Dubkovetska II, Voronych VO. Strukturni zminy endoteliyu endokarda livogo shlunochka shchuriv u pislyastresovomu periodi. Art of medicine. 2017; 4(4):1924.

7. Sadlyak OV. Endoteliy yak regulyator imunnykh, zapalnykh ta vilnoradykalnykh protsesiv, oposeredkovanykh systemoyu L-arginin-oksyd azotu. Med. khimiya. 2013; 15(4):96-9.

8. Khorosh MV. Modernizatsiya sposobu zhuttya yak sposib pervynnoyi profilaktyky sertsevo-sudynnoyi patologiyi. Ukrayina. Zdorovia natsiyi. 2016; 1/2:212-7.

9. Lami AA, Abdelhamed AI, Arqam Z, Hala FO, Zaki A, Agha M. Naringenin adds to the protective effect of 1arginine in monocrotaline-induced pulmonary hypertension in rats: Favorable modulation of oxidative stress, inflammation and nitric oxide. European Journal of Pharmaceutical Sciences. 2014; 62(3):161-170.

10. Santuzzi CH, Tiradentes RV, Mengal V, Claudio ERG, Mauad H, Gouvea SA, Abreu GR. Combined aliskiren and L-arginine treatment has antihypertensive effects and prevents vascular endothelial dysfunction in a model of renovascular hypertension. Braz J Med Biol Res. 2015; 48(1):24.

\section{УДК 577.122.385+616-085+612.176+616.126+615.03 \\ ВЛИЯНИЕ L-АРГИНИНА И ОСОБЕННОСТИ ФАРМАКОКОРЕКЦИИ СОСТОЯНИЯ ЭНДОТЕЛИЯ СЕРДЦА КРЫС В УСЛОВИЯХ ДЕЙСТВИЯ ЭМОЦИОНАЛЬНО-БОЛЕВОГО СТРЕССА, ОСЛОЖНЁННОГО ГИПЕРХОЛЕСТЕРИНЕМИЕЙ}

И.Н. Лучко, Т.В. Гуранич, О.И. Тучак, С.А. Петруняк, И.О. Назарук

Ивано-Франковский национальный медищинский университет, кафедра физиологии,

2. Ивано-Франковск, Украина,

ORCID ID: 0000-0003-3282-0890,

e-mail: fisiology@ifnmu.edu.ua

Резюме. Целью работы было изучение состояния эндотелия эндокарда крыс (по количеству отслоённых клеток) при эмоционально-болевом стрессе, осложненном гиперхолестеринемией в условиях применения L-аргинина (как субстрата для синтеза оксида азота) и ряда других фармакологических препаратов. Для воспроизведения стресса использовалась электроимпульсная модель. Алиментарную гиперхолестеринемию моделировали путём содержания животных на атерогенной диете. Кроме L-аргинина, применяли следующие 
фармакологические препараты: $\beta$-адреноблокатор пропранолол, блокатор $\mathrm{Ca}^{2+}$-каналов финоптин и блокатор циклооксигеназ индометацин. Состояние эндотелия эндокарда изучали с помощью светооптической микроскопии, анализируя мазкиотпечатки с макропрепаратов желудочков. Установлено, что пероральное использование Lаргинина существенно предупреждает повреждение эндотелиоцитов эндокарда при эмоциональноболевом стрессе и является неэффективным при стрессе, осложнённом гиперхолестеринемией. Среди других фармакологических препаратов выраженным цитопротекторным действием при стрессе обладают пропранолол и финоптин. В условиях стрессорного воздействия гиперхолестеринемия существенно ограничивает защитное действие упомянутых препаратов. Полученные результаты и их анализ позволяют предположить, что в патогенезе структурно-функциональных изменений эндотелиоцитов эндокарда и развития эндотелиальной дисфункции в условиях эмоционально-болевого стресса, а также при его сочетании с гиперхолестеринемией важным звеном является токсическое действие катехоламинов, которые влияют на функциональные системы организма преимущественно через $\beta$ адренорецепторы (с участием ионов $\mathrm{Ca}^{2+}$ ). Определенную защитную роль играют, по-видимому, простагландины, поскольку блокада их синтеза индометацином усугубляет повреждение эндотелиоцитов.

Ключевые слова:

аргинин, фармакологические препараты, эндотелий, стресс, гиперхолестеринемия.

UDC 577.122.385+616-085+612.176+616.126+615.03

INFLUENCE OF L-ARGININE AND FEATURES OF PHARMACOLOGICAL CORRECTION OF THE RAT'S HEART ENDOTHELIUM STATE IN CONDITIONS OF EMOTIONAL PAIN STRESS COMPLICATED BY

HYPERCHOLESTEROLEMIA

I.M. Luchko, T.V. Huranych, O.I. Tuchak, S.O. Petrunyak, I.O. Nazaruk

Ivano-Frankivsk National Medical University, Department of Physiology, Ivano-Frankivsk, Ukraine, ORCID ID: 0000-0003-3282-0890,

e-mail: fisiology@ifnmu.edu.ua

Abstract. Nowadays the main pathoendotelioropic factors are poorly studied: stress and increased of blood free cholesterol, and ability to use with the protective purpose of L-arginine as a main substrate for the synthesis of nitric oxide (NO). The purpose of the work was to study the endothelium of myocardium (by number of flattened cells) with emotionally-painful stress, complicated with hypercholesterolemia, in the conditions of application of L-arginine and a number of other pharmacological means. To reproduce the stress electric pulse model was used. Alimentary hypercholesterolemia was simulated in animals with the atherogenic diet. In addition to L-arginine, the following pharmacologic agents were applied: $\beta$-adrenoblocator Propranolol, blocator of $\mathrm{Ca}^{2+}$ channels Phynoptin and blocator of cycloxygenases Indomethacin. The endothelium state of endocard was studied by using optical microscop, analyzing strokes-Prints from ventricular macropreparations. As the results, the use of L-arginine before stressors in animals, which received regular food, limits damage to endothelial surface by $22,2 \%$ was defined. At the same time, its application in conditions of combined action of stress and hypercholesterolemia does not give a significant positive result. Among other studied pharmacological means expressed cytoprotective action on the endothelium of left ventricle endocardium of rats have propranolol and phynoptyn, that in emotionally-painful stress reduce the desqamation of endoteliocytes in accordance with $63,9 \%$ and $40,1 \%$. Introduction of indomethacin before the action of stress, on the contrary, accompanied by strengthening (by 33,3\%) endothelial cell peeling. At stress, complicated hypercholesterolemia, the previous tendency is retained in the applied medication action, but their pharmacological effect is less expressed. Under the influence of Propranolol and Phynoptyn, endothelium damage of endocard decreases, but to a lesser extent, than in the action of one only stressful factor (respectively by $51,9 \%$ and $26,9 \%$ ). The use of indomethacin in these conditions leads to reinforcement the desqamation of endotheliocytes by $50 \%$. The protective effect of Larginine (as NO donator) on the endothelium is connected, obviously, with two mechanisms: the reduction of the intracellular concentration of $\mathrm{Ca}^{2+}$ ions through activation in the endoteliocytes cytoplasmic guanilatcyclase and inhibition of platelet aggregation to the surface of these cells.

As a result, their analysis and comparison with the data of other literary sources, make the following conclusions: a) oral use of L-arginine significantly prevents endothelium of endocardium damage in the case of emotionally painful stress and is ineffective in stress, complicated hypercholesterolemia; b) in the pathogenesis of structural and functional changes of endoteliocytes and the development of endothelial dysfunction in the conditions of emotionally-painful stress and its combination with hypercholesterolemia as important component is the toxic action of catecholamines, affecting the functional systems of the body mainly via $\beta$ adrenoreceptors and with the participation of $\mathrm{Ca}^{2+}$ ions. Prostaglandins, obviously, play a protective role, because the blockade of their synthesis by indomethacine deepens the damage of endothelium; c) hypercholesterolemia of alimentar origin potentiates damaging effects of stress on endothelium endocardium, accompanied by a sharp increase in the number of desqamatory cells, and, on the other hand, limits the protective effects of certain pharmacological drugs.

Keywords: arginine, pharmacological means, endothelium, stress, hypercholesterolemia.

Стаття надійшла в редакцію 5.11.2019 р. 